Maja Smrdu, Urban Kordeš

\title{
Pregled nekaterih fenomenov v športni psihologiji z doživljajskega vidika
}

Ključne besede: športna psihologija, fenomenologija, flow, zavestna pozornost (mindfulness), metakognicija

V uvodu članka bomo najprej na kratko predstavili stanje na področju športne psihologije. Osredotočili se bomo predvsem na aplikativni del in vedno večjo potrebo po uporabi fenomenoloških idej. Fenomenologija ima dvojni pomen: epistemološko razjasnitev in metodološko uporabnost $\mathrm{v}$ okviru kvalitativnega empiričnega raziskovanja, usmerjenega na doživljajsko področje. $\mathrm{V}$ pričujočem članku se bomo osredotočili na prvi pomen fenomenologije, tako da si bomo poskušali razjasniti pogosto uporabljene pojme $\mathrm{v}$ športni psihologiji. Razmislek o fenomenološkem raziskovanju pa nam bo pomagal pri konceptualni razjasnitvi pojmov.

Obravnavali bomo fenomene, ki jih v športni psihologiji povezujemo z uspešnostjo, kot so flow, ${ }^{1}$ zavestna pozornost (mindfulness) ${ }^{2}$ in metakognicija. Pri omenjenih pojmih bomo poskušali razčistiti, s katerega vidika gledajo na duševne fenomene: prvoosebnega ali tretjeosebnega. Flow je tipičen pojem, ki govori o prvoosebni perspektivi, opisuje namreč doživljajski dogodek ali stanje. Velikokrat pa se nereflektirano povezuje $\mathrm{z}$ vedenjskim stanjem, ki bi mu lahko rekli uspešnost. V članku bomo razmislili o smiselnosti takšnih povezav in poskušali določiti odnose med naštetimi pojmi.

$\mathrm{V}$ zaključku članka bomo primerjali še fenomenološki epoché s konceptom zavestne pozornosti.

\section{$1 \quad$ Stanje v športni psihologiii}

Še do sredine devetdesetih so bile praktično vse raziskave v športni psihologiji kvantitativne (Biddle idr., 2001; Culver idr., 2003), od takrat pa se število kvalitativnih študij povečuje (Kerr, Males, 2010; Nesti, 2011).

1 Mestoma se kot prevod za »flow « uporablja beseda »zanos«, vendar se s tem prevodom ne strinjamo, ker ima jasno pozitivno čustveno komponento, ki je originalno pojmovanje flowa (nujno) ne zajema.

2 Menimo, da prevod čuječnost, ki se občasno uporablja, ni najbolj ustrezen, saj implicira zgolj zvišano budnost, medtem ko se izraz mindfulness uporablja za zavestno usmerjanje pozornosti na zunanje in notranje dogodke, in sicer brez presojanja. Besedna zveza zavestna pozornost pa predvideva tako zavestno usmerjanje pozornosti kot golo opazovanje dogajanja, brez kakršnegakoli vrednotenja. 
Zadnje čase na področju športa ter zlasti psihologije in sociologije športa opažamo vedno večje zanimanje za fenomenologijo. Po dolgem obdobju, v katerem so se različni vidiki športne aktivnosti (npr. motivacija, anksioznost, kohezivnost ekipe, dinamika ipd.) preučevali $\mathrm{z}$ uporabo različnih psiholoških vprašalnikov in $\mathrm{s}$ kvantitativnim raziskovanjem, je Fawcett (2010) koncept mentalne čvrstosti preučil z uporabo fenomenoloških metod. Predlagal je, da bi bile športni psihologiji sicer dobro znane tematike, kot sta anksioznost in samozavest, podvržene fenomenološkim raziskavam, saj je čas, da se tudi športna psihologija posveti pomenu in ne več kvantifikaciji ter meritvam (Nesti, 2001). To je toliko bolj upravičeno, ker prevladujočemu pristopu v športni psihologiji, ki večinoma sloni na kognitivno vedenjski psihologiji, ni uspelo natančno opredeliti nekaterih psiholoških konstruktov, kot je npr. anksioznost. Kot poroča Nesti (2011), prav pregled študij anksioznosti pokaže pomanjkljivosti kvantitativnega pristopa. Kljub temu, da je to eden najbolj preučevanih pojavov $\mathrm{v}$ športni, zlasti tekmovalni situaciji, raziskovalci nanj samo dodajajo nove in nove spremenljivke, ne uspe pa jim identificirati njegovega bistva. Namesto da bi se približali natančni definiciji, gredo $\mathrm{v}$ drugo smer in $\mathrm{v}$ nikoli dokončnem procesu dodajajo spremenljivko za spremenljivko.

Poleg tega se številni pomembni koncepti, ki vplivajo na praktično delo, $\mathrm{v}$ raziskavah redko pojavljajo. Termini živega sveta tekmovalnega športa, kot so pogum, duh, identiteta in pomen, se malo preučujejo. Ali kot pravi Crust (2005), je področje športne psihologije, povezano $\mathrm{z}$ optimalno izvedbo, pri raziskovalcih presenetljivo pogosto spregledano, saj so raziskave večinoma osredotočene na to, kako premagati negativna psihološka stanja, kot je anksioznost. Bistveno manj pa je znanega o pozitivnih subjektivnih doživetjih (stanjih zavedanja), ki so v literaturi različno poimenovana, npr. vrhunska izkušnja (peak experience), optimalna izkušnja (optimal experience), vrhunska izvedba (peak performance) ali flow. Flow je nedvomno fenomen, ki ga je težko meriti in kvantificirati s psihometričnimi tehnikami (Crust, $2005,49)$ in pri katerem se lahko pokaže moč fenomenološke metode.

Športna psihologija je vse bolj razdeljena na dva tabora, na raziskovalnega, ki poudarja pomen teorije, in aplikativnega, ki poudarja praktično delo s športniki, pogosto brez teoretske podlage (Nesti, 2011). Fenomenološki pristop pa lahko pomaga pri premagovanju te razdvojenosti, pri spoznavanju jedra posameznih fenomenov, ki so že precej preučevani, ter nam odpre vrata do doslej raziskovalno zanemarjenih področij.

Iz navedenega je razvidno, da raziskovalci na področju športne psihologije prepoznavajo omejitve kvantitativnega raziskovanja, hkrati pa se kaže tudi zmeda na področju razlikovanja posameznih pojmov, npr. združevanja vedenjske ravni oziroma 
izvedbe in doživljanja. Kvalitativne metode se kažejo kot bolj primerne za raziskovanje doživljajskih in drugih procesov, pri katerih je bistveno poznavanje geštalta oziroma celostnega individualnega vidika. Opozarjajo pa tudi, da je za epistemološko smiselnost in metodološko veljavnost rezultatov zelo pomembno zavedanje raziskovalne perspektive. $\mathrm{V}$ primeru raziskovanja duševnih procesov pri športnikih (npr. anksioznosti, flowa, zavestne pozornosti) poznavanje vedenjskih vzorcev še ne pomeni, da lahko iz njih sklepamo na doživljanje ali obratno (če je športnik v stanju flowa, to nujno še ne pomeni, da dosega vrhunske rezultate). Neupoštevanje ali nereflektirano posploševanje izven izbranih okvirov je najpogostejša napaka pri raziskovanju duševnih fenomenov. In prav fenomenologija je bistveno pripomogla $\mathrm{k}$ razumevanju in epistemološki jasnosti stanja.

\section{Fenomenologija}

Fenomenologija - kot jo obravnavamo v pričujočem besedilu in kot se uporablja v psihologiji - sicer temelji na filozofskem delu Edmunda Husserla in Maurica Merleau-Pontyja, vendar je $\mathrm{v}$ zadnjih desetletjih dobila novo obliko kot empirična raziskovalna disciplina, še posebej na področju kognitivne znanosti. Sodobna interdisciplinarna prizadevanja pri raziskovanju duševnih procesov kažejo, da je treba izenačiti razumevanje obeh osnovnih perspektiv, s katerih lahko opazujemo (in raziskujemo) duševne procese: tretjeosebne (ki vključuje opazovanje vedenja in nevrofiziološke raziskave) in prvoosebne (preučevanje človekovega izkustva). Še do nedavnega je bil doživljajski vidik duševnih fenomenov obravnavan kot nekakšno nujno zlo, ki ga je treba karseda omejiti, če ga že ne moremo izločiti. V psihologiji so ga poskušali reducirati in zajeti z opredelitvijo posameznih splošnih značilnosti (največkrat s pomočjo vprašalnikov), vendar se je s tem izgubila epistemološka razlika med doživljajskim in vedenjskim vidikom (prvoosebnim in tretjeosebnim vidikom). Mnogi opisi in definicije ne ločujejo med perspektivama - kljub temu, da so z vsako od perspektiv povezani povsem drugačni epistemološki in metodološki okviri. Prav zmeda pri razlikovanju omenjenih perspektiv je kriva za številna nerazumevanja pri raziskovalnem in aplikativnem delu.

\subsection{Fenomenološko raziskovanje}

Ne glede na metodološke težave se $\mathrm{v}$ zadnjih desetletjih kaže potreba po empiričnem fenomenološkem raziskovanju, torej sistematičnem raziskovanju doživljanja kot »se nam kaže« (Husserl, 2006). V zgodovini se je zvrstilo že več pobud za tovrstna raziskovanja (Goethe, po Seamon, Zajonc, 1998; nemški introspekcionisti, npr. Wundt, 2010 itd.), zadnja pa prihaja s področja kognitivne znanosti. Kljub 
skokovitemu napredku na področju raziskovanja nevrofiziologije je namreč vse bolj jasno, da nam razumevanje procesov v živčevju ne pomaga prav dosti, če ne poznamo doživljajskih fenomenov, ki jih ti procesi porajajo.

S fenomenologijo inspirirano oziroma, krajše, fenomenološko raziskovanje se osredotoča na opazovanje živega, neposrednega izkustva. Na kratko povedano: fenomenologija se zavzema za raziskovanje izkustva, ne da bi se spuščala v metafizično ali teoretsko spekulacijo.

Temelj, ki ga fenomenološko raziskovanje povzema po fenomenološki filozofiji, je spoznanje o primarnosti izkustva (oziroma prvoosebnega doživljanja); spoznanje, ki ga je Husserl opisal z besedami: nazaj k stvarem samim. Ne le, da je primarno: je vse, kar imamo - ničesar ne moremo spoznati izven polja svojega doživljanja. Misli, pomeni, opisi, vizije, slike, občutki, čustva ... nič od tega ni izven zavestnega doživljanja (oziroma lastnega živega izkustva). Doživljajski svet seveda lahko urejamo (npr. z razdelitvijo na čustva, misli itd. ali z znanstveno razlago opaženega), ne moremo pa spoznati ničesar, kar bi bilo izven lastnega izkustva.

Opisana epistemološka drža je tisto, kar fenomenološko raziskovanje (kot kvalitativno-metodološka smer) povzema po fenomenologiji kot filozofski disciplini. Fenomenološko raziskovanje lahko torej v splošnem definiramo kot metodološko kategorijo, ki zajema vse empirične raziskovalne metode, pristope, načine zbiranja in/ ali analize gradiva, ki temeljijo na zgoraj opisanih (fenomenoloških) epistemoloških temeljih ter smernicah. V nadaljevanju se bomo posvetili orisu te dokaj nove raziskovalne smeri, zlasti na področju športa.

Nekaj osnovnih metodoloških smernic Husserlovega raziskovalnega načrta: ${ }^{3}$

Osredotočenje na fenomene (stvari, kot se kažejo v našem izkustvu) in epoché postavljanje v oklepaje. Husserl predlaga "puščanje običajnih privzetkov o stvareh ob strani« (oziroma dajanje le-teh v »oklepaje«) in fenomenološko redukcijo - redukcijo opazovanega na fenomene »kot tisto edino, kar je dano v izkustvu in gotovo«. Kot piše Kotnik $(2003,102)$, je poudarek na »raziskovanju danega izključno v izkustvu, toda vključeno mora biti celotno izkustvo in prvi korak je spoznavanje kompleksnosti in neskončnosti tega polja«.

Pravilo: »Ne razlagaj, ampak opisuj!« To je najpomembnejša metodološka smernica fenomenološkega raziskovanja. Morda se zdi navodilo na prvi pogled preprosto, vendar je njegova izvedba zelo kompleksna ter zahteva dobršno mero refleksije in spretnosti. Šele ko v praksi poskusimo samo opisovati doživljanje, ne da bi ga kakorkoli

3 Smernice povzemamo po poenostavljenem, a odličnem pregledu fenomenologije v Kotnik (2003, 102) - od tod so vse dobesedne navedbe, ki delno sledijo Ihdeju (1977, 32-45). 
klasificirali, umeščali v teoretske okvire, pojasnjevali ipd., se zavemo, kako globoka je naša potreba po razlagi in kako težko se ji izognemo. Kotnik (prav tam) citira Ihdeja, ki govori o »težavnosti razlikovanja med dejansko opisljivim izkustvom, kot se kaže samo kot neposrednost, in neizkustvenimi elementi, kot so domneve ali predpostavke. Razlaga je namreč kakršnakoli teorija, ideja, pojem ali konstrukcija, ki teži v ozadje fenomenov.«

Vzdržimo se prepričanj oziroma ocenjevanj »realnosti« opaženih fenomenov. Brez intersubjektivnega preverjanja (ki je značilno za znanstveno metodo) ne moremo razločiti med »iluzijo« in »resničnostjo«. Z vidika primarnosti neposrednega izkustva je takšno razlikovanje le en način urejanja doživljajskega sveta (in torej nima višje vrednosti od drugih možnih razlikovanj), zato Husserl priporoča, da celo to - na videz tako primarno sodbo - postavimo v oklepaj in opazujemo polje izkustva, kot se kaže, brez presojanja.

Ker se je Husserlu zdelo, da bi samo z zgornjimi navodili ostali »izgubljeni med fenomeni« (prav tam), je dodal še četrto smernico, ki priporoča iskanje strukture in konstantnih značilnosti opazovanih fenomenov. Husserl je verjel, da je na tak način mogoče ustvariti »transcendentalno « znanost - torej sistem, ki presega samo enkratno minljivo konkretno izkustvo in iz njega izloči bistvene (transcendentalne) elemente.

\subsection{Zemljevid pojmov}

Fenomenološko raziskovanje je zelo širok pojem in - ker je še v povojih - dodobra nedefiniran. Mescht $(2004,2)$ piše:

Pojem »fenomenološko raziskovanje« nima samo enega pomena - različni avtorji ga pojmujejo različno. Zaradi njegove subjektivne in kvalitativne narave nekateri pripisujejo pridevnik »fenomenološko« $\mathrm{k}$ vsakemu intrinzično interpretativnemu kvalitativnemu raziskovanju. Glede tega, kaj sploh je predmet fenomenološkega raziskovanja, še ni popolnega soglasja. Ne toliko zato, ker se raziskovalci s tega področja med sabo ne bi strinjali, ampak bolj zato, ker so - kot smo že omenili - različne verzije poročil o doživljanju nujni del mnogih področij raziskovanja. Navadno si raziskovalci ne vzamejo veliko časa za razglabljanje o tem, kako pridobiti fenomenološke podatke (»phenomenoal data«), oziroma o tem, kaj takšni podatki sploh so. Navadno je spregledano dejstvo, da preprosto spraševanje (»just ask« attitude) niti približno ni zadovoljivo (prav tako kot, recimo, v fiziki ni dovolj, da samo pogledamo naravni pojav).

Fenomenološko raziskovanje se poleg fenomenološke tradicije opira na spoznanja zgodnjih psiholoških poskusov introspekcije (Wundt, Titchener itd.) in se uči iz 
njihovih napak. Številni fenomenološki raziskovalci se navdihujejo tudi pri t. i. praksah "zavestne pozornosti« (kot sta meditaciji zazen ali vippashana in njune izpeljanke $\mathrm{v}$ sodobni psihoterapiji).

Metodologija fenomenoloških raziskav je zelo kompleksna, saj vključuje tako bolj introspektivne kot tudi bolj strukturirane metode (npr. vprašalnike), predvsem pa so zanjo značilne študije primera. Vse metode pa temeljijo na istem odnosu do doživljanja; posameznikovemu doživljanju se zaupa, jemlje se ga tako, kot se kaže, in se izogiba sodbam. V nadaljevanju bomo podrobneje pisali o tem odnosu in ga primerjali $\mathrm{z}$ odnosom zavestne pozornosti.

\section{Združevanje fenomenologije in športne psihologije}

Veliko športnih psihologov čuti, da se je v športni psihologiji začelo meriti in kvantificirati, preden se je želene predmete preučevanja sploh razumelo. Postalo je jasno, da je pristop, ki pokaže uporabne rezultate v laboratoriju, pogosto manj uporaben v resničnem svetu. Nesti (2011) razmišlja, da je športna psihologija potrebovala toliko časa, da se je začela posluževati tudi fenomenološke raziskovalne metode, zaradi terminologije, ki je tako drugačna od psihološke in jo je morda na prvi pogled težko razumeti (npr. lived world, being-in-the-world). Dodaten zaostanek lahko povzroča tudi dejstvo, da fenomenološki pristop zavrača akcijsko usmerjen pogled, medtem ko je tak pogled glavna usmeritev športne psihologije. Glede na potrebo po boljšem razumevanju psiholoških pojavov pri športnikih je treba razumeti njihovo izkušnjo, za kar jih moramo povabiti k opisu njihovega doživljanja v vsakdanjem jeziku, z njihove lastne perspektive. To je skladno s Husserlovo zahtevo, da se moramo vrniti $\mathrm{k}$ »stvarem samim«. Pustiti moramo, da nam podatki govorijo neposredno, ne da bi nanje vplivali $s$ teoretiziranjem ali načrtovanjem intervencij. $Z$ drugimi besedami, dokler natančno ne vemo, s čim imamo opravka, se moramo vsaj zadržati pred določanjem, kako naj se fenomen obravnava. Pri praktično usmerjenih psihologih pa je to večkrat v nasprotju $\mathrm{z}$ njihovo tendenco po takojšnji izboljšavi športnikovega rezultata. Pri tem pozabijo, da je posledica te tendence, brez jasnega poznavanja doživljanja posameznega fenomena, omejena in običajno kratkotrajna. Področje fenomenologije v športni psihologiji se je dodatno odpiralo, ker so psihologi začeli prepoznavati prav to omejenost lastne kvantitativne metode in spoznanj, dobljenih na njeni osnovi.

Najpogostejši cilj aplikativne športne psihologije je pomoč pri doseganju vrhunske izvedbe oziroma rezultatov, zato si poglejmo, kako lahko k razumevanju tega prispeva fenomenološka metoda. Različne študije so poskusile razkriti značilnosti optimalnega športnega nastopa. Nesti (2011) povzema, da je bilo opisanih več konceptov pozitivnih izkušenj, kot so: vrhunska izkušnja (peak experience) (Privette, 1981; Ravizza, 
1984), vrhunska izvedba (peak performance) (Cohn, 1991; Privette, 1981) in flow (Csikszentmihalyi, 1975, 1988, 1990). Že iz tega je razvidno, da so športni psihologi neupravičeno mešali vedenjsko raven in doživljanje, kar je pogosto še danes. Flow in vrhunska izkušnja opisujeta bolj doživljajsko raven, vrhunska izvedba pa vedenjsko. Obe ravni sta med seboj prav gotovo povezani, flow marsikdaj (vendar ne nujno) spremlja vrhunsko izvedbo; kljub temu pa je njuno enačenje neupravičeno.

\subsection{Flow kot doživljajski korelat vrhunske izvedbe}

Flow večinoma opredeljujemo kot zvišano stanje zavesti, ki odseva spremembe pozornosti (Crust, 2005). Csikszentmihalyi (1990) ga je definiral kot optimalno mentalno stanje, ki vključuje popolno vpetost $\mathrm{v}$ trenutno nalogo ali aktivnost, ob kateri športnik, ne da bi se za to zavestno odločil, izgubi zavedanje za vse ostalo: čas, ljudi, distraktorje in celo osnovne telesne potrebe. Skupaj z Jacksonom (1999) sta predstavila devet značilnosti izkušnje flowa:

a) občutek ravnovesja med visokimi zahtevami situacije in osebnimi spretnostmi športnika. Kadar so izzivi in spretnosti simultano nad povprečjem, se sproži širša pozitivna izkušnja;

b) občutek popolne osredotočenosti na trenutno nalogo;

c) zlivanje akcije in zavedanja oziroma občutek avtomatičnosti lastnih akcij;

d) jasno definirani cilji oziroma športnikov občutek prepričanosti v prihajajoča dejanja;

e) nedvomna povratna informacija: športnik prejme takojšnjo in jasno povratno informacijo, ki potrjuje, da vse poteka po načrtu;

f) občutek kontrole, ki se dogaja brez zavestnega napora, simultano sta povezana visoka raven spretnosti in občutek, da za to ni potreben noben napor;

g) distorzija časa: športnik lahko čas zaznava počasneje ali hitreje, lahko pa je zmanjšano njegovo zavedanje minevanja časa;

h) izguba zavedanja sebe: športnika ne skrbi, ali ga drugi presojajo ali ocenjujejo in tudi sam nima tovrstnega odnosa do sebe, temveč postane eno $\mathrm{z}$ aktivnostjo;

i) notranje nagrajujoča izkušnja: športnik občuti ugodje, ker nekaj počne zaradi aktivnosti same, ne da bi pričakoval nagrado ali drugo korist.

Palmer (2006) ugotavlja, da lahko doživetje flowa spremeni tudi vzorce gibanja, saj postanejo zavestni gibi in nezavestne refleksne funkcije bolje integrirane, kar izboljša koordinacijo. Veliko športnikov opisuje, kako so brez napora izvedli svoj nastop, hkrati pa dosegli najboljši osebni rezultat.

Voznik formule ena Ayrton Senna je svoj kvalifikacijski nastop za Veliko nagrado Monaka leta 1988 opisal takole: 
Imel sem že zagotovljeno prvo štartno pozicijo, vendar sem kar nadaljeval. Naenkrat sem bil skoraj dve sekundi hitrejši od ostalih. Nenadoma sem spoznal, da formule ne vozim več zavestno. Vozil sem jo nekako instinktivno, samo bil sem v drugi dimenziji. Bilo je, kot da bi bil v tunelu.

»Mislil sem brez misli, zaupal sem v svoje početje. V zadnji borbi sem prvič $\mathrm{v}$ življenju dal sebi in svoji duši čisto veselje ob bitki, ne da bi se zavedal občinstva, «pa navaja športnikov opis Orlick $(2008,140)$. Umetnostna drsalka Wong je svojo flow izkušnjo zanimivo poimenovala kot »vključitev svojega avtopilota«.

Zaradi vsega opisanega so športni psihologi začeli sklepati, da je posledica flowa vedno tudi vrhunska izvedba, dober rezultat ali pa »vsaj« nov zagon za aktivno športno udejstvovanje, zato so začeli iskati tehnike, s katerimi bi lahko športnike pripeljali do tega stanja ali vsaj povečali možnost zanj.

\subsection{Poskusi doseganja stanja flowa}

\section{Metakognicija}

Aplikativna športna psihologija večinoma sloni na kognitivno vedenjski terapiji in njeni paradigmi, tako da je začela hitro vključevati njena znanja, pri čemer je bil poudarek na metakogniciji kot tehniki za izboljšanje nastopa. Posledica tega je, da se pri psihološki pripravi športnika še vedno poudarja kognitivne procese in se jih pojmuje kot poglavitne dejavnike $\mathrm{v}$ procesu odločanja. $\mathrm{Z}$ metakognicijo je zavedanje sebe začelo pridobivati na pomembnosti tako $\mathrm{v}$ procesu treninga kot tekmovanja.

J. H. Flavell (1979) je prvi uporabil izraz »metakognicija« za posameznikove kognitivne procese ali druge procese, povezane $\mathrm{z}$ njimi. Označuje raven mišljenja, ki vključuje aktivno kontrolo uporabljenih miselnih procesov. Spretnosti, ki so že po svoji naravi metakognitivne, so: načrtovanje načina učenja, kontroliranje razumevanja, evalvacija napredka, vzdrževanje motivacije in napora ob izvajanju naloge ter sposobnost zavedanja motečih dražljajev (notranjih in zunanjih).

Metakognicija se lahko deli (Hartman, 2001) na izvršitveni management in strateško znanje. Prvi vključuje načrtovanje, spremljanje, evalvacijo in revidiranje posameznikovih miselnih procesov in dognanj. Strateško znanje pa zajema: znanje kaj (deklarativno znanje), znanje $k d a j$ in zakaj (kontekstualno znanje) in znanje kako (proceduralno znanje). Oba dela metakognicije sta potrebna za samoregulacijo mišljenja in učenja.

Metakognicija vsebuje tri komponente:

- metakognitivno znanje (imenovano tudi metakognitivno zavedanje): kaj posameznik ve o kognitivnih procesih pri sebi in drugih; 
- metakognitivno regulacijo, ki je regulacija kognicije in učnih izkušenj;

- metakognitivno izkušnjo; povezana je s trenutno, odvijajočo se kognitivno aktivnostjo.

V splošnem velja, da so ljudje z bolj razvitimi metakognitivnimi ali izvršitvenimi funkcijami tudi bolj uspešni pri učenju, saj hitreje zaznavajo učne blokade in temu ustrezno prilagodijo strategije. Metakognicija je torej zelo koristna pri učenju novih spretnosti, postavljanju ciljev in opazovanju lastnih čustvenih stanj, po drugi strani pa izjave športnikov kažejo, da je lahko med nastopom celo moteča in uniči izvedbo. To je razvidno zlasti pri športih s kompleksnimi koordinacijskimi zahtevami (npr. gimnastika) in pri športih, pri katerih je ključnega pomena časovna uskladitev (npr. smučarski skoki). Tako je smučarski skakalec poročal: »Poglaviten je timing odskoka, in če razmišljam, kdaj se moram odriniti, ga ne bom nikoli zadel, preprosto moram imeti občutek. Če imam občutek timinga v nogah, potem vem, da sem v formi.« Ritmična gimnastičarka je izvedbo težke prvine, ki zahteva vzdrževanje ravnotežja $\mathrm{v}$ obratu, zanoženje s predklonom, vrtenje ter met in prijem rekvizita, opisala takole: »Prvina se mora izvajati sama od sebe, če pomislim, da moram popraviti nogo ali kaj spremeniti, se mi kompletno poruši. « Podobno je lahko že pri ustaljenem zaporedju vaje, gimnastičarka je poročala: "Med vajo sem začela razmišljati in sem pozabila, kako gre naprej, kateri element je naslednji, in to pri vaji, ki sem jo izvedla tisočkrat, katere zaporedje znam, če me zbudijo sredi noči. « Izkušnje športnikov tako kažejo, da je uporaba metakognicije lahko koristna, po drugi strani pa lahko zato, ker praktično povsem sloni na kognitivni dejavnosti, ob njeni pretirani aktivaciji v temeljih razgradi športnikov nastop.

\section{Zavestna pozornost}

Psihologi so $\mathrm{v}$ letih prakticiranja tehnik metakognicije torej ugotovili, da te tehnike (npr. samogovor, dihalne tehnike, postavljanje ciljev) sicer večkrat izboljšajo tekmovalno izvedbo, vendar večkrat ne pripeljejo do vrhunske izvedbe. Izkazalo se je, da racionalni del ne uravnava (nujno) celostnega človekovega delovanja (Kahneman, 2003), zato so psihologi iz vzhodnih duhovnih tradicij vpeljali zavestno pozornost, ki predvideva bolj celostno delovanje človeka. V športni psihologiji pa so jo začeli uporabljati tudi kot metodo za doseganje flowa.

Termin mindfulness je prevod (T. W. Rhys Davis, 1881) palijske besede sati in označuje Budddhovo priporočilo k vsakodnevnemu vzdrževanju, kolikor je le mogoče, mirne pozornosti na telesne funkcije, občutke, objekte zavedanja (misli in zaznav) in zavest samo (Wynne, 2007, 73). Zahodna psihologija je termin ohranila, vendar je njegov pomen in uporabo prilagodila. Tako je zavestna pozornost v zahodni kulturi definirana kot "na sedanjost usmerjena pozornost, ki ni ocenjujoča ali presojajoča» 
(Kabat-Zinn, 2003, 2). Cottraux (2007) jo je označil kot mentalno stanje, do katerega pride zaradi prostovoljnega usmerjanja posameznikove pozornosti na senzorne, mentalne, kognitivne in čustvene vidike trenutne izkušnje. Zavestna pozornost na sedanji trenutek je dejanje brez cilja, povezano s prehodno odložitvijo tako ega (Ryan in Brown, 2003) kot interpretacije izkušnje (Shapiro idr., 2006). Kadar je športnik zavestno prisoten, opazuje trenutek brez presojanja in se vzdrži pripisovanja osebnih vrednosti odvijajočemu se procesu. V novejših konceptualizacijah je zavestna pozornost opredeljena kot učinkovita kognitivna samoregulacija, ki se kaže v točnosti ocenjevanja in neavtomatičnosti odziva (Garland idr., 2009; Shapiro idr., 2006).

Novejše študije $\mathrm{v}$ športni psihologiji so poskusile ugotoviti povezavo med zavestno pozornostjo in športno izvedbo (Gardner, Moore, 2006; Kee, Wang, 2008). Ugotovile so, da bodo športniki, ki so bolj zavestno osredotočeni na sedanji trenutek, tudi bolj verjetno doživeli stanje flowa. Hkrati pa bolj izražena zavestna pozornost označuje tudi boljše metakognitivne spretnosti, kot so kontrola pozornosti, čustvena kontrola, postavljanje ciljev in samogovor. Raziskave so tako pokazale, da je zavestna usmerjenost v jedru vrhunskega nastopa (Jackson, Csikszentmihalyi, 1999; Ravizza, 2002).

$\mathrm{V}$ športni psihologiji razlikujemo dve ključni komponenti zavestne pozornosti (Bishop idr., 2004): (1) lastno regulacijo pozornosti oziroma zavedanje trenutne izkušnje in (2) odnos radovednosti, odprtosti in sprejemanja trenutne izkušnje. Zavedanje in sprejemanje notranjih in zunanjih vidikov trenutne izkušnje, ob neocenjujočem sprejemanju, spremljanju misli, občutkov in čustev, brez izogibanja ali pretirane vključenosti, prinese s sabo tudi čustveno stabilnost (Carmody, 2009; Delgado idr., 2010).

Plavalec Matjaž Markič je svoj nastop na evropskem prvenstvu, na katerem je osvojil bronasto kolajno, opisal takole:

Ves čas do nastopa sem verjel, da bom dal vse od sebe in da bom pokazal svoj letošnji najboljši nastop prav na najpomembnejši tekmi sezone. Zelo sem bil samozavesten in prepričan v svoje sposobnosti, vedel sem, da če mi uspe odplavati tako, kot sem sposoben, bom zagotovo blizu medalje. No, moram priznati, da sem dvakrat le pomislil, ali sem dovolj dobro pripravljen; $\mathrm{v}$ to nisem bil najbolj prepričan, ker sem imel v pripravljalnem obdobju zdravstvene težave in pet dni pred tem nastopom nisem najbolje plaval $\mathrm{v}$ enkrat daljši disciplini. $\mathrm{V}$ teh trenutkih sem pomislil na to, kar sva se $\mathrm{s}$ psihologinjo pogovarjala in dogovorila: da se moram osredotočiti samo na ta nastop in razmišljati samo, kako bom pravilno odplaval celo tekmo. Ko sem pa enkrat stopil na štartni kamen, sem začel razmišljati le, na kaj moram 
paziti, da bom vse naredil optimalno. Na vrsti je bil štart in do cilja sem bil ves čas skoncentriran samo na svoje plavanje. Tudi tekmeci, ki so plavali zraven mene, me niso dekoncentrirali, ker sem bil tako zbran, da se mi je zdelo, da sem sam v bazenu. (Kajtna in Jeromen, 2007, 108)

Vidimo lahko, da termin zavestna pozornost uporabljamo na dva načina. Po eni strani označuje stanje doživljanja, po drugi pa tehniko psihološke priprave. Tako npr. Gardner in Moore (2004) navajata kot posledico intervenc, usmerjenih na zavestno pozornost, sprejemanje negativnih misli, zmanjševanje skrbi, povečano uživanje, koncentracijo in vztrajanje.

Zavestno pozornost se tako uporablja tudi kot tehniko za kontrolo čustvenih stanj s pomočjo namenske oddaljitve tako od čustev kot od misli. Od tega načina procesiranja se pričakuje (Wells, 2001), da bo olajšal:

a) razvoj metakognitivnega načina delovanja, pri katerem misli niso zaznane kot resničnost, ampak samo kot mentalni dogodki, ki jih je mogoče oceniti in spremeniti;

b) zmanjšanje vključenosti v strategije, ki slonijo na skrbi in jih vodi slabo prilagojeno vedenje;

c) fleksibilnost odgovorov na grožnjo;

d) razvoj načrtov za kontrolo kognicije.

Študije, ki obravnavajo zavestno pozornost, se zapletajo v kontradikcije. Zavestno pozornost popolnoma enačijo s »samoregulacijo kontrole pozornosti« (Clark, 2002; Bishop idr., 2004) in poudarjajo razvijanje njene spretnosti skozi različne tehnike (npr. tehnike dihanja, samogovora), hkrati pa govorijo o dejanju in pozornosti brez ciljev in ega ter o kognitivni inhibiciji (Bishop idr., 2004; Ryan idr., 2003). Če bi pogledali na to fenomenološko, bi odkrili, da gre (vsaj) za različne oblike pozornosti, ki jih je treba razločevati ob teh različnih pojmovanjih. Popolnoma pa je spregledano, da zavestna pozornost označuje tudi odnos do duševnih pojavov in da jo prav zaradi tega vidika lahko bolje razumemo.

Če izpostavimo ključne značilnosti zavestne pozornosti - usmerjena je na doživljajsko polje, kot se kaže, ob odsotnosti ocenjevanja, presojanja in interpretacije nima ciljne orientacije in je povezana s prehodnim umikom ega -, postane očitno, da je izjemno sorodna fenomenološkemu epochéju. Fenomenologija je prav tako usmerjena na posameznikovo doživljanje žive izkušnje (Varela, 1999), ki jo poskuša opisovati in razumeti brez kakršnihkoli predpostavk ali interpretacij. Epoché pa bi lahko primerjali s prehodnim umikom ega, kot ga poznamo pri praksi zavestne pozornosti. Po Husserlu je za človeško doživljanje značilen naraven odnos, ki obsega običajen način doživljanja sveta, vključno z vsemi samoumevnimi predpostavkami in vedenji, ki jih imamo 
(Langdridge, 2007). Cilj epochéja je postavljanje tega »naravnega odnosa«v oklepaje. Na neki način je fenomenološki odnos zelo soroden odnosu zavestne pozornosti, saj vključuje zavedanje vsega, kar doživljamo (tudi avtomatizmov in predpostavk), tako kot to velja tudi za zavestno pozornost.

\section{$4 \quad$ Intergracija}

Glede na to, da je cilj aplikativne športne psihologije običajno izboljšanje športnikove izvedbe, smo z doživljajskega vidika pogledali fenomene, ki jo spremljajo. K boljšim športnim rezultatom običajno pripomoreta tako metakognicija kot zavestna pozornost, vendar je resnično vrhunska izvedba najpogosteje povezana s stanjem flowa (ki ga ne moremo zavestno sprožiti). Tendence športne psihologije so trenutno močno usmerjene v raziskovanje, kako čim pogosteje priti do tega stanja.

$\mathrm{Na}$ osnovi raziskav je jasno, da metakognicija večinoma pozitivno vpliva na športnikov nastop, vendar ima tudi svojo past, saj pretirana uporaba misli v tekmovalni situaciji popolnoma zruši nastopno rutino. Medtem ko je jasno, da imajo športniki, ki večkrat doživijo flow (in zavestno pozornost), tudi boljše metakognitivne sposobnosti, obratna situacija ni tako jasna - namreč da izboljšanje metakognitivnih spretnosti poveča verjetnost za flow (Kee, Wang, 2008). Z drugimi besedami: izboljšava nastopa $\mathrm{v}$ tem primeru ni zelo verjetno pogojena s pogostejšimi stanji flowa. S tem lahko že potrdimo, da je razvijanje metakognitivnih sposobnosti za tekmovalni šport smiselno, vendar ne $\mathrm{z}$ namenom doseganja stanja flowa.

Raziskave kažejo, da je zavestna pozornost povezana s flowom, da športniki, ki večkrat doživijo stanje flowa, kažejo tudi boljše sposobnosti za vzpostavljanje in vzdrževanje zavestne pozornosti. Športniki pa tudi poročajo, da so po učenju tehnik zavestne pozornosti večkrat doživeli stanje flowa, a kljub temu zavestna pozornost pogosto ne sproži stanja flowa (Kee, Wang, 2008). Za oba fenomena je značilna določena čustvena ločenost in oddaljenost od trenutne situacije. Ključna razlika pa je, da pri zavestni pozornosti športnik namensko usmerja svojo pozornost in miselni tok, medtem ko se pri flowu vse to dogaja avtomatično in brez športnikovega namenskega poseganja v kognitivne procese. Potemtakem bi moral športnik, če bi želel iz stanja zavestne pozornosti priti do stanja flowa, narediti dva pomembna preskoka: spremeniti mentalno usmerjenost $\mathrm{v}$ neusmerjenost in preiti iz celostnega, neselektivnega opazovanja na ozko opazovanje posameznega dela situacije ( $\mathrm{tj}$. tekmovalne izvedbe) ter vztrajati pri tem kot opazovalec. Tako ostaja odprto vprašanje, ali se je, glede na to potrebno kompleksno spremembo doživljanja, smiselno učiti zavestne pozornosti $\mathrm{z}$ namenom doseganja flowa. Za odgovor na to vprašanje bi bilo treba izvesti dodatne fenomenološke empirične raziskave. 
Že prej smo izpostavili zanimive podobnosti med zavestno pozornostjo in fenomenologijo; za obe je značilen enak opazujoč in egodistanciran odnos do sveta. $\mathrm{V}$ fenomenoloških študijah udeleženci poročajo o pomembnem izboljšanju zavestne pozornosti, ki se običajno pojavi po treh dneh fenomenološkega samoraziskovanja (npr. z metodo vzorčenja izkustva; Clark, 2002). To kaže, da fenomenološka metoda, prav tako kot zavestna pozornost, zahteva metazavest.

Ob epistemološkem poznavanju zavestne pozornosti in njene uporabe v športni psihologiji je mogoče opaziti zanimiv paradoks. Zavestna pozornost je namreč $v$ osnovi stanje brez ciljne usmerjenosti, medtem ko se jo v športni psihologiji uporablja prav s ciljem, in sicer za izboljšanje dosežka. Tako flow kot zavestna pozornost sta stanji, za kateri je značilno bogato in svojsko doživljanje, kjer je večkrat prisoten tudi občutek zadovoljstva, medtem ko je (vsaj vrhunski) šport strogo usmerjen v doseganje rezultatov in ga ne zanimata niti doživljanje niti zadovoljstvo (če ni povezano $\mathrm{Z}$ motivacijo in vztrajanjem $\mathrm{v}$ športni karieri).

Psihološki trening vrhunskega športa pa je paradoksalen tudi glede na to, da od športnikov (največkrat) zahteva neposreden odnos na tekmovališču (npr. sosednje tekmovalne proge), hkrati pa je športnik (običajno) najuspešnejši ravno takrat, kadar je na tekmovališču notranje sam. V športu se pojavlja tudi etični paradoks, ki kaže, da je šport paradoksalen način človekovega delovanja. Športniki namreč med sabo hkrati tekmujejo in sodelujejo (to velja zlasti za ekipne športe), kar od športnika zahteva, da je hkrati prijatelj in »nasprotnik«.

Poleg že opisanih povezav fenomenologije $\mathrm{z}$ nekaterimi športnimi koncepti je nedvomno njen ključni pomen, da pomaga športni psihologiji epistemološko razumeti fenomene, ki jih obravnava. Poleg tega se vedno znova izkaže, da udeležencem v raziskavah daje več informacij (in posledično koristi) o lastnem funkcioniranju kot kvantitativne študije in da so športniki na koncu zadovoljni (večkrat tudi pozitivno presenečeni), medtem ko imajo do kvantitativnih raziskav največkrat negativen odnos. Glede na to, da fenomenologija kot raziskovalna metoda aplikativnim športnim psihologom (in športnikom) pogosto ponudi več uporabnih informacij kot kvantitativne raziskovalne metode, je lahko tako tudi povezovalni most med - sedaj tako razdvojeno - teoretično in aplikativno smerjo.

\section{Zaključek}

Športni psihologi v zadnjih letih vedno bolj spoznavajo omejitve kvantitativnega raziskovanja in posledično omejeno poznavanje fenomenov, ki jih preučujejo. Tako so se začeli obračati na kvalitativne raziskovalne metode, med katerimi daje zlasti 
fenomenološka največji doprinos k razumevanju doživljajskega sveta športnikov in ima s tem povezovalno funkcijo med teoretično in praktično usmeritvijo športne psihologije. Fenomenologija se osredotoča na pomen fenomenov in raziskuje bistvo človekovega doživljanja. To je lepo razvidno pri fenomenih, ki zajemajo različne ravni samozavedanja, kot so zavestna pozornost, flow in metakognicija. S fenomenološko metodo postane vsak fenomen zase in s tem tudi razlikovanje med fenomeni bolj jasno, kar pomaga tudi športniku pri njegovem funkcioniranju.

\section{Literatura}

Biddle, S. J. H. in drugi, Research Methods in Sport and Exercise Psychology: quantitative and qualitative issues, Journal of sport science 10, 2009, str. 777-809.

Bishop, S. R. in drugi, Mindfulness: a proposed operational definition, Clinical Psychology: Science \& Practice 11 (3), 2004, str. 230-241.

Clark, S. R., The impact of self-regulated attention control on the amount of time spent in flow, Dissertation Abstracts International 5, 2002, str. 2615B.

Cottraux, J., Thérapie cognitive et emotions: La troisième vague [Cognitive therapy and emotions: The third wave], Paris 2007.

Crust, L., Flow: For peak experiences in sport, you need to go with the flow, v: Psychology a will to win (ur. Walker, I.), London 2005, str. 43-50.

Csikszentmihalyi, M., Flow: The psychology of optimal experience, New York 1990.

Csikszentmihalyi, M., The flow experience and its significance for human psychology, v: Optimal experience: psychological studies of flow in consciousness (ur. Csikszentmihalyi, M.), Cambridge, UK 1988, str. 15-35.

Culver, D. M. in drugi, A decade of qualitative research in three sport psychology journals: 1990-1999, The Sport Psychologist 17, 2003, str. 1-15.

Delgado, L. C. in drugi, Treating chronic worry: Psychological and physiological effects of a training programme based on mindfulness, Behaviour Research and Therapy 48, 2010, str. 873-882.

Flavell, J. H., Metacognition and cognitive monitoring: A new area of cognitivedevelopmental inquiry, American Psychologist 34, 1979, str. 906-991.

Gardner, F. L., Moore, Z. E., A Mindfulness-Acceptance-Commitment (MAC) based approach to performance enhancement: Theoretical considerations, Behavior Therapy 35, 2004, str. 707-723.

Gardner, F. L., Moore, Z. E., Clinical sport psychology, Champaign, IL 2006. 
Garland, E. in drugi, The role of mindfulness in positive reappraisal, Explore 5 (1), 2009, str. 37-44.

Hartman, H. J. (ur.), Metacognition in learning and instruction, Dordrecht 2001.

Husserl, E., Izraz in pomen: raziskave $k$ fenomenologiji in teoriji spoznanja, Ljubljana 2006.

Ihde, D., Experimental phenomenology, New York 1977.

Jackson, S. A., Csikszentmihalyi, M. C., Flow in sports: The keys to optimal experiences and performances, Champaign, IL 1999.

Jackson, S. A., Roberts, G., Positive performance states of athletes: Toward a conceptual understanding of peak performance, The Sport Psychologist 6, 1992, str. 156-171.

Kabat-Zinn, J., Wherever you go, there you are: mindfulness meditation in everyday life, New York 1994.

Kahneman, D., A perspective on judgment and choice: Mapping bounded rationality, American Psychologist 58 (9), 2003, str. 697-720.

Kajtna, T., Jeromen, T., Šport z bistro glavo, Ljubljana 2007.

Kee, Y. H., Wang, C. K. J., Relationship between mindfulness, flow dispositions and mental skills adoptions, Psychology of Sport and Exercise 9, 2008, str. 393-411.

Kerr, J. H., Males, J. R., The experience of losing: Qualitative study of elite lacrosse athletes and team performance at a world championship, Psychology of Sport and Exercise 11, 2010, str. 394-401.

Kordeš, U., How to research experience?, v: Philosophical insights about modern science (ur. Žerovnik, E. in drugi), Hauppauge, NY 2009, str. 215-232.

Kotnik, R., Pouk filozofije kot osebno doživljanje: izkustveno poučevanje filozofije kot aplikacija načel Gestalt terapije (Knjižna zbirka Učbeniki, 5), Maribor 2003.

Langdridge, D., Phenomenological psychology: Theory, research and method, Harlow 2007.

Mescht, H. Van der, Phenomenology in Education: A Case Study in Educational Leadership, Indo-Pacific Journal of Phenomenology 4, 2004, str. 1.

Metcalfe, J., Shimamura, A. P., Metacognition: knowing about knowing, Cambridge, MA 1994.

Nesti, M., Sport psychology and spirit in professional football, v: Theology, ethics and transcendence in sports (ur. Parry, J. in drugi), London 2001.

Nesti, M., Phenomenology and sport psychology: back to the things themselves, Sport, ethics and philosophy 5 (3), 2011, str. 285-296.

Orlick, T., In pursuit of excellence, Champaign, IL 2008. 
Palmer, R., Zone mind, zone body, Penryn, UK 2006.

Petranker, J., Inhabiting Conscious Experience: Engaged Objectivity in the FirstPerson Study of Consciousness, Journal of consciousness studies 10, 2003, str. 12.

Ryan, R. M., Brown, K. W., Why we don't need self-esteem: on fundamental needs, contingent love and mindfulness, Psychological inquiry 14, 2003, str. 27-82.

Seamon, D., Zajonc, A., Goethe's Way of Science: A Phenomenology of Nature, Albany, NY 1998.

Shapiro, S. L. in drugi, Mechanisms of mindfulness, Journal of Clinical Psychology 62, 2006, str. 373-386.

Ulmer, C. S. in drugi., Mindfulness and acceptance are associated with exercise maintenance in YMCA exercisers, Behaviour Research and Therapy 48, 2010, str. 805-809.

Varela, F., Shear, J., The View from Within, Exeter 1999.

Wells, A., GAD, metacognition, and mindfulness: an information processing analysis, Clinical Psychology: Science and Practice 9, 2002, str. 95-100.

Wundt, W., Principles of physiological psychology, Charleston, SC 2010.

Wynne, A., The origin of Buddhist Meditation, Abingdon, Oxon 2007, str. 73. 
Maja Smrdu, Urban Kordeš

\section{Review of some phenomena in sport psychology from the point of view of the athlete's experience}

Keywords: sport psychology, phenomenology, flow, mindfulness, metacognition

Although many quantitative studies have been carried out on various aspects of sport, it seems our understanding of them has not advanced considerably. Because of that there has been a greater acceptance of qualitative methods and with that also the value of employing phenomenological approaches in the academic discipline of sport psychology has increased in recent years. Phenomenological psychology can allow us to look more closely to athletes' experiences and therefore plays a mediating role between applied and theoretical aspects of sport psychology. We find its special importance at phenomena connected to peak performance and different stages of consciousness. 